\title{
Synthesis and Characterization of Niobium Carbide with Copper Addition Obtained Via Gas Solid Reaction
}

\author{
Maria Veronilda Macedo Souto * (D), Camila Pacelly Brandão de Araujo ${ }^{b}$, Maria José Santos Lima ${ }^{a}$, \\ Filipe Martel Magalhães Borges ${ }^{c}$ (D) Uilame Umbelino Gomes ${ }^{a}$, Carlson Pereira de Souza ${ }^{b}$ \\ ${ }^{a}$ Departamento de Ciência e Engenharia de Materiais, Universidade Federal do Rio Grande do Norte, \\ Natal, RN, Brasil \\ ${ }^{b}$ Laboratório de Materiais Nanoestruturados e Reatores Catalíticos, Departamento de Engenharia \\ Química, Universidade Federal do Rio Grande do Norte, Natal, RN, Brasil \\ ${ }^{c}$ Escola de Ciência e Tecnologia, Universidade Federal do Rio Grande do Norte, Natal, RN, Brasil
}

Received: December 20, 2016; Revised: October 17, 2017; Accepted: January 18, 2018

The use of niobium containing materials' has gained much attention of the scientific community in the late years due its various applications in diverse fields. $\mathrm{NbC}$ is a highly versatile material. Copper addition may alter several of its properties, such as morphology, crystal structure etc. as well as enhance its catalytic behavior. Nanostructured $\mathrm{NbC}$ with copper addition synthesis' presented here had the precursor $\left[\left(\mathrm{NH}_{4}\right)_{3}\left[\mathrm{NbO}\left(\mathrm{C}_{2} \mathrm{O}_{4}\right)_{3}\right]_{\mathrm{x}} \mathrm{H}_{2} \mathrm{O}\right]$ as starting material, which was doped with $\mathrm{Cu}\left(\mathrm{NO}_{3}\right)_{2}$ at $5 \%$ and $10 \%$ (molar) ratios. Doped $\mathrm{NbC}$ was obtained via gas solid reaction in fixed bed reactor at lower temperature $\left(980^{\circ} \mathrm{C}\right)$ and with shorter reaction time $(2 \mathrm{~h})$ than traditional methods. Reaction products' were characterized by XRD, crystal sizes were estimated according to HWL method, and SEM, XRF, BET and laser particle size analysis were performed. XRD indicated the formation of $\mathrm{NbC}$ and $\mathrm{Cu}$ phases with cubic crystal structure of $\sim 20 \mathrm{~nm}$. SEM showed slight morphological change upon increasing copper content, indicating a less porous structure, which is consistent with BET data $\left(43.7 \mathrm{~m}^{2} / \mathrm{g}\right.$ for $5 \% \mathrm{Cu}-\mathrm{NbC}$ and $37 \mathrm{~m}^{2} / \mathrm{g}$ for the $\left.10 \% \mathrm{Cu}-\mathrm{NbC}\right)$. Crystal size calculations showed that increasing dopant content particle sizes were also increased, probably due to the presence of the dopant, in some extent, in the crystal structure.

Keywords: Niobium carbide, copper, gas solid reaction, fixed bed reactor.

\section{Introduction}

Recently, the development of materials with various applications has become a major industrial interest; in that sense, researches have been developed considering and thus aiming to change synthesis conditions or parameters, so that time and energy requirements can be minimized and, ideally, more versatile materials can be obtained. Refractory metals' carbides are highly versatile materials as their range of proprieties is wide: extreme hardness, resistance to degas, excellent resistance to high temperature (high melting point), etc. ${ }^{1,2}$.

Industrial production of these materials, however, is only possible through highly energetic processes at elevated temperatures $\left(>1300^{\circ} \mathrm{C}\right)^{5}$ for long residence times (over $6 \mathrm{~h})^{6}$, which makes the production of nanoscale products difficult $^{7}$. The development of reaction routes that apply lower temperatures and reaction times, such as the one presented in this paper, could be more interesting economically and industrially, not to mention the gains in materials' properties (nanoscale products, higher superficial area, etc.).

Among refractory carbides, niobium carbide has received much attention of the scientific community due to its valuable

*e-mail Veronilda.macedo@gmail.com set of proprieties, among which its extreme hardness [ $>235 \mathrm{GPa}]$ is worth notice ${ }^{3,4}$. Besides, niobium materials are a topic of interest as Brazil holds the majority of its minerals' reserves and the development of fully finished products is important in a strategically point of view.

Niobium carbide is a highly versatile material as it has applications on the metallurgy industry, aerospace industry, and others, as well as on the catalytic field. Especially for hydrodesulphurization reactions of oil refining industries for environmental compliance, carbide catalysts have been found to be excellent reacting materials ${ }^{9,10}$. For its use as catalysts, carbides are required to present high surface areas, small particle sizes, as well as a surface free from pollutants, such as free carbon, that can impair the catalytic reaction ${ }^{11,12}$. Niobium based catalysts are effective in different processes, such as hydrogenation, oxidation, esterification, polymerization, and condensation reactions ${ }^{13}$.

Usually, in those catalytic reactions a promoting metal is used ${ }^{14}$. Often enough these metals are com Ni${ }^{+2}, \mathrm{Co}^{+2}, \mathrm{Cu}^{+}$. Souza et al. ${ }^{15}$ produced chromium-copper composites and upon evaluating the synergistic effect of those metals, concluded that the addition of $\mathrm{Cu}$ caused structural modification of the original catalysts and activated catalytic sites, thus increasing its activity. Samir et al. ${ }^{16}$ also used a copper composite in 
organic catalytic reactions and owed to copper addition the catalytic gain observed.

For the synthesis of niobium carbide with the copper addition high energy milling followed by sintering is the traditional route. In this process metallic copper and graphite are used as starting materials ${ }^{17,18,19}$. This methodology, however, leads to powders with larger particle sizes and require long processing times. The TPR method (temperature programmed reaction) is an alternative to produce these materials with high particle size control due to the increased interaction between gas and solid phases in the reaction process ${ }^{20}$. In addition, the gas solid route provides means for faster species diffusion as higher mass transfer velocities can be attained in comparison to traditional metallurgic route where diffusion happens in liquid phase, thus providing a faster method for producing this material.

In this paper, niobium carbide with copper addition was synthesized by gas solid reaction from a niobium oxalic precursor and copper nitrate in a fixed bed reactor. This precursor's use for the synthesis of niobium powders has been proved feasible and interesting as it presents higher reactivity than the commercial niobium pentoxide ${ }^{21}$. Other authors $^{22}$ have successfully produced $\mathrm{NbC}$ in shorter time and temperature using this material as niobium source. ${ }^{23}$ tested $\mathrm{Nb}$ oxide powders derived from this material for the oleic acid esterification reaction, and owed to the precursor the higher yield achieved in comparison to commercially available $\mathrm{Nb}_{2} \mathrm{O}_{5}$. In addition the use of the complex precursor in comparison to commercially available $\mathrm{Nb}_{2} \mathrm{O}_{5}$ powder may lead to smaller particle sizes and more porous materials ${ }^{24}$. This is an interesting industrial gain as final products may suffer crystal growth during use.

Copper was used as doping metal, as it is known to enhance catalytic activity in several reaction systems. This study was performed in order to evaluate the effect of copper addition over niobium carbide, which is a well-known material. The process was studied in two compositional levels with both materials being produced via gas solid reaction in a fixed bed reactor with a methane/hydrogen gas atmosphere.

\section{Materials and Methods}

Copper doped niobium carbide $(\mathrm{Cu}-\mathrm{NbC})$ was synthesized via gas solid reaction in a fixed bed reactor using as a starting material finely grained precursor ammoniobium (V) oxalate $\left[\left(\mathrm{NH}_{4}\right)_{3}\left[\mathrm{NbO}\left(\mathrm{C}_{2} \mathrm{O}_{4}\right)_{3}\right]_{\mathrm{x}} \mathrm{H}_{2} \mathrm{O}\right]$ doped with copper nitrate $\left(\mathrm{Cu}\left(\mathrm{NO}_{3}\right)_{2}\right.$, Sigma Aldrich, 99,99\%). The complex precursor was synthesized according to the methodology indicated by Souto $(2016)^{21}$. The dopant addition was carried out by simple physical mixture of powders in the solid state with an agate mortar and pestle until visual uniformity of the powder. Copper was added at 5 and $10 \%$ molar $\mathrm{Cu} / \mathrm{Nb}$ ratios.

In order to obtain the doped carbide, approximately $2 \mathrm{~g}$ of this doped precursor were added to an alumina crucible, which was loaded to an alumina fixed bed reactor $\left(\mathrm{d}_{\mathrm{ext}}=35 \mathrm{~mm}, \ell\right.$ $=80 \mathrm{~cm}$ ) coupled with a resistance furnace (EDG Túnel FTHI40 , Brazil), where the gas solid reaction was carried out.

Once the reactor chamber was sealed, the reactor was purged with Argon flow for approximately 30 minutes. Then, reactant gas flow was started at a total flow rate of $20 \mathrm{~L} / \mathrm{h}$ with $5 \% \mathrm{CH}_{4}$ (Linde, Brazil, 99.9\%) and 95\% $\mathrm{H}_{2}$ (Linde, Brazil, $95 \%$ ). The decomposition/reduction/carburization reactions were carried out with a $10^{\circ} \mathrm{C} \cdot \mathrm{min}^{-1}$ heating rate, from room temperature to $980^{\circ} \mathrm{C}$. At this temperature the reactor was held for 120 minutes. By the end of the reaction, the gas atmosphere was switched back to argon atmosphere, until room temperature was achieved.

The reaction products were characterized by XRF (SHIMADZU EDX-720, air atmosphere), SEM (SHIMADZU MEV SSX550 with 3 to $8 \times 10^{3}$ amplifications), XRD (SHIMADZU XRD- 6000, Cu-K $\alpha$, at $30 \mathrm{kV}$ and $30 \mathrm{~mA}$, $2^{\circ} \cdot \mathrm{min}^{-1}$ ) and BET (Micrometrics, ASAP 2020). Crystal sizes estimates were performed according to HWL integral calculations from the XRD pattern and from Reitveld refinement data. Laser particle size analysis was performed at CILAS 920 equipment, from $0.30-400 \mu \mathrm{m}$, with water as dispersive media.

\section{Results and Discussion}

\section{1. $\mathrm{Cu}-\mathrm{NbC}$ characterization}

\subsubsection{XRD evaluation and Reitveld's refinement}

Table 1 presents diffraction angles' shift of the doped niobium carbides. Values identified by $\left(^{*}\right)$ are of a reference pattern data for pure niobium carbide. Slight angle shifts can be noted on the doped products. This is associated to copper presence on the composite microstructure as verified by other authors for other refractory metal doped carbides ${ }^{25}$.

Table 1. Diffraction angles' shift due to Copper addition in comparison to pure $\mathrm{NbC}$.

\begin{tabular}{ccc}
\hline \multirow{2}{*}{ Reference pattern } & $\begin{array}{c}5 \% \mathrm{Cu} \\
\Theta\end{array}$ & $\begin{array}{c}10 \% \mathrm{Cu} \\
\Theta\end{array}$ \\
\hline 34.40 & 34.69 & 34.69 \\
40.05 & 40.27 & 40.28 \\
- & - & 43.28 \\
- & - & 50.56 \\
58.01 & 58.69 & 58.30 \\
69.40 & 69.66 & 69.67 \\
73.00 & 73.25 & 73.26 \\
\hline
\end{tabular}

Figure 1 presents the XRD pattern for the 5\% and $10 \%$ copper added $\mathrm{NbC}(\mathrm{NbC}, 44355-\mathrm{ICSD})$. The reaction products presented complete conversion to carbides with cubic structure, as indicated by other authors ${ }^{26,27}$. With higher dopant content (Figure 2, top) new peaks arise at $\theta=43.28^{\circ}$ 
e $\theta=50.56^{\circ}$ which are characteristic of metallic copper $(*)$ (43493- ICSD) which forms a single copper phase. On the lower compositional level (Figure 2, bottom), this could not be verified, either by the dispersion of the metal on the crystal structure or due to its low content.

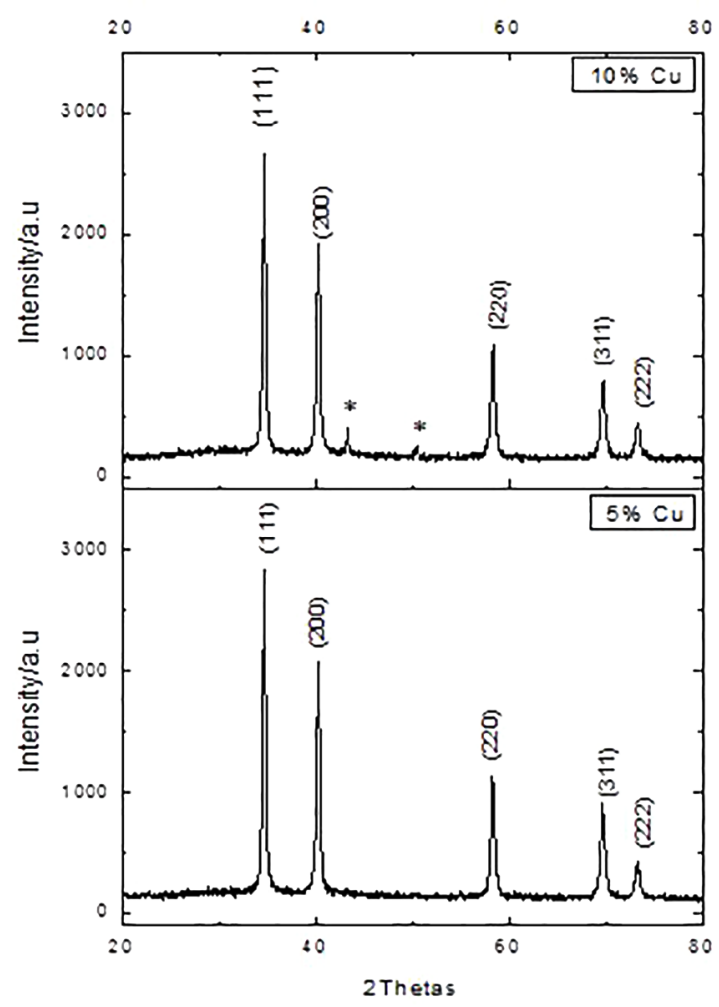

Figure 1. XRD patterns for $5 \% \mathrm{Cu}-\mathrm{NbC}$ (bottom) and $10 \% \mathrm{Cu}-$ $\mathrm{NbC}$ (top).

In face of the identified phases, and the thermal decomposition profile of the precursor used as starting material ${ }^{8}$ the following reaction path is proposed:

$2\left(\mathrm{NH}_{4}\right)_{3} \mathrm{NbO}\left(\mathrm{C}_{2} \mathrm{O}_{4}\right)_{3} \cdot \mathrm{H}_{2} \mathrm{O}(\mathrm{s})+2 \mathrm{Cu}\left(\mathrm{NO}_{3}\right)_{2} \cdot 3 \mathrm{H}_{2} \mathrm{O}(\mathrm{s}) \rightarrow \mathrm{Nb}_{2} \mathrm{O}_{5}(\mathrm{~s})$ $+2 \mathrm{CuO}(\mathrm{s})+6 \mathrm{NH}_{3}(\mathrm{~g}) \uparrow+6 \mathrm{CO}(\mathrm{g}) \uparrow+6 \mathrm{CO}_{2}(\mathrm{~g}) \uparrow+4 \mathrm{NO}_{2}(\mathrm{~g}) \uparrow$ $+11 \mathrm{H}_{2} \mathrm{O}(\mathrm{g}) \uparrow+\mathrm{O}_{2}$

$1^{\text {st }}$ step $=$ thermal decomposition of both starting materials: niobium complex and copper nitrate producing niobium oxide and copper oxide as distinguished solid phases though mixed.

$$
\begin{aligned}
& \mathrm{Nb}_{2} \mathrm{O}_{5}(\mathrm{~s})+2 \mathrm{CuO}(\mathrm{s})+3 \mathrm{H}_{2}(\mathrm{~g}) \rightarrow 2 \mathrm{NbO}_{2}(\mathrm{~s})+2 \mathrm{Cu}(\mathrm{s})+2 \\
& \mathrm{H}_{2} \mathrm{O}(\mathrm{g}) \uparrow
\end{aligned}
$$

$2^{\text {nd }} \mathrm{step}=$ oxides' reduction by hydrogen atmosphere.

$2 \mathrm{NbO}_{2}(\mathrm{~s})+2 \mathrm{Cu}(\mathrm{s})+3 \mathrm{CH}_{4}(\mathrm{~g}) \rightarrow 2 \mathrm{Cu}-\mathrm{NbC}(\mathrm{s})+\mathrm{CO}(\mathrm{g}) \uparrow+$ $3 \mathrm{H}_{2}(\mathrm{~g}) \uparrow+3 \mathrm{H}_{2} \mathrm{O}(\mathrm{g}) \uparrow$

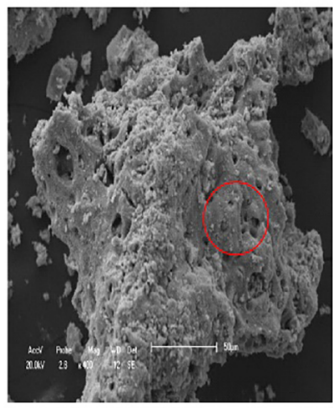

(A) $400 \mathrm{x}$

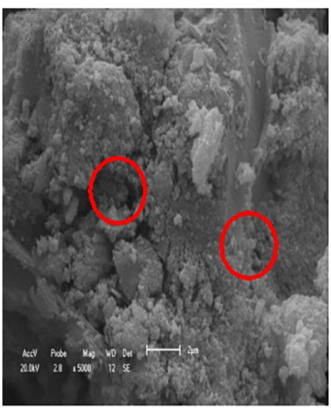

(C) $5000 \mathrm{x}$

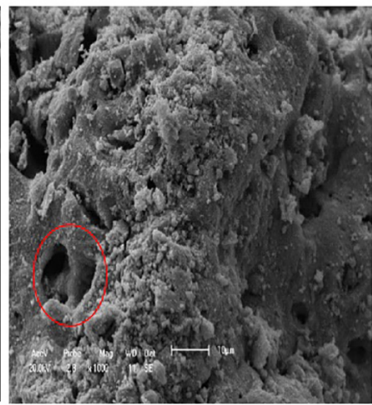

(B) $1000 \mathrm{x}$

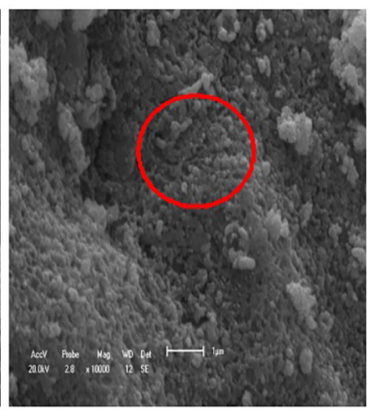

(D) $10000 \mathrm{x}$
Figure 2. SEM images for 5\% copper doped niobium carbide with magnifications of (A) 400x and (B) 1000x, highlighted regions indicating agglomerating behavior of the powder. (C) with 5000x magnifications and (D) with10000x. Highlighted regions indicate the presence of two phases.

$3^{\text {rd }}$ step $=$ carbon addition to the niobium structure, copper presence as a disperse metal in the carbide structure forming $\mathrm{Cu}-\mathrm{NbC}$ composite.

We understand that, as XRD patterns indicates the presence of some of the copper as a metallic phase, part of the copper oxide is reduced to metal $\mathrm{Cu}$ and part was able to enter the $\mathrm{NbC}$ structure (as shown in Table 1). $2^{\text {nd }}$ and $3^{\text {rd }}$ steps may occur simultaneously as the gas atmosphere both reduces and carburizes the solid.

\subsubsection{Crystal size estimates}

Crystal sizes' estimates of the reaction products were carried out according to HWL integral calculations, based on XRD patterns data. They are presented on Table 2 . Determination coefficients $\left(\mathrm{R}^{2}\right)$ as well as micro strain $(\varepsilon)$ estimates are also presented. All reactions produced nano scale powders. It can be observed an increase in particle sizes with increasing dopant content. This may be due to the insertion of the dopant, to some extent, in the crystal structure. ${ }^{22}$ while studying the synthesis of pure $\mathrm{NbC}$ from the same starting material was able to obtain crystal sizes of $\sim 16 \mathrm{~nm}$. Therefore, the addition of the dopant in fact alters the crystal arrangement, causing its increase in comparison to the un-doped material. 
Table 2. Crystal size estimates for reaction products.

\begin{tabular}{lccc}
\hline Sample & HWL $(\mathrm{nm})$ & $\varepsilon$ & $\mathrm{R}^{2}$ \\
\hline $5 \% \mathrm{CuNbC}$ & 20.85 & 0.001 & 0.89 \\
$10 \% \mathrm{CuNbC}$ & 22.53 & 0.001 & 0.80 \\
\hline
\end{tabular}

\subsubsection{SEM evaluation}

Figures 2 and 3 present SEM images for the reaction products. Figure 2 refers to $5 \%$ copper added niobium carbide, whereas Figure 3 refers to $10 \%$ copper powder.

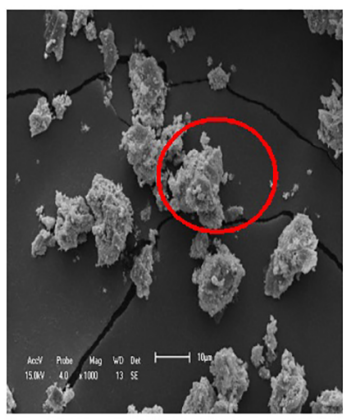

$A(1000 x)$

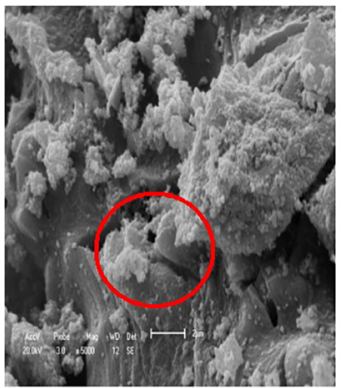

$\mathrm{C}(5000 \mathrm{X})$

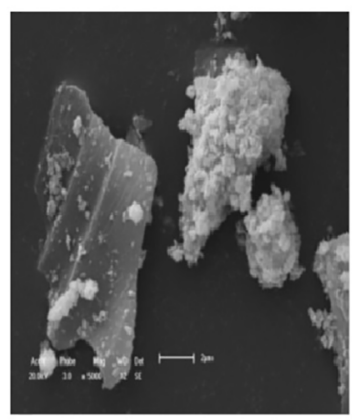

$\mathrm{B}(5000 \mathrm{x})$

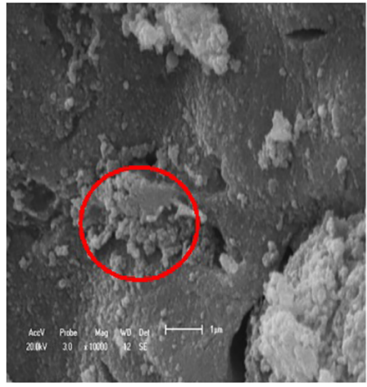

$\mathrm{D}(10000 \mathrm{x})$
Figure 3. SEM images for $10 \%$ copper doped niobium carbide with magnifications of (A) 1000x and (B) 5000x, highlighted regions indicating agglomerating behavior of the powder. (C) with $5000 \mathrm{x}$ magnifications and (D) with10000x. Highlighted regions indicate the presence of two phases.

On Figure 2A (400x) and 2B (1000x) a uniform morphology is revealed as well as an agglomerating characteristic of the material. Highlighted regions indicate various pore sizes. On Figures 2C (5000x) and 2D (10000x), two phases can be distinguished and these are attributed to niobium carbide and metallic copper. The morphology indicated by the highlighted regions' is that of fine powders with various sizes that agglomerate in a disordered manner. This is characteristic of nanoscale compounds and is attributed to Van der Walls forces, which become more pronounced and intense in materials formed by nanoparticles. ${ }^{12}$ suggests that this is due to growth of coalesced nuclei, making the resulting particles to stick together in a process towards reducing the superficial area and thus, reducing the free energy by decreasing interface/surfaces of the powder. Therefore, the $5 \%$ doped carbide presents larger agglomerates, as crystal sizes are smaller and the particles tend to be more attracted by those weak forces.

On Figure 3 SEM images of the 10\% copper added niobium carbide are presented. Slight morphological changes could be observed upon increasing the dopant content. The material seems less porous than its pair at lower compositional level. On Figure 3A and 3B, a tendency towards forming platelet shaped material can be observed. This could be due to the decrease in porosity verified for this material due to the increased dopant addition. This is consistent with crystal size calculations presented on section 3.2.1. On Figure 3C and $3 \mathrm{D}$, highlighted regions indicate once more the presence of two different phases; this was also verified by XRD data (section 3.1.1).

In comparison to pure niobium carbide powders produced by gas solid reaction by other authors ${ }^{3,22,26,28}$ the dopant presence promoted only slight morphological alteration, mainly related to the porosity of the produced carbide, which was lower for doped materials.

\subsubsection{X-ray fluorescence}

$\mathrm{XRF}$ analysis was also performed in order to evaluate the elemental composition of the powders. Table 3 presents compositional data. Once again the intended and achieved were in agreement and the effective presence of the dopant on the produced powder was verified.

Table 3. $\mathrm{Cu}$ content on doped carbides by XRF.

\begin{tabular}{lc}
\hline Sample & $\% \mathrm{Cu} / \mathrm{Nb}(\mathrm{mol} / \mathrm{mol})$ \\
\hline $5 \% \mathrm{Cu}-\mathrm{NbC}$ & 4.040 \\
$10 \% \mathrm{Cu}-\mathrm{NbC}$ & 9.612 \\
\hline
\end{tabular}

\subsubsection{Pore size and surface area evaluation by BET method.}

Superficial area of both compounds was evaluated by BET method and is presented on Table 4. These results are lower than the ones observed by other authors ${ }^{8}$ for pure $\mathrm{NbC}\left(62.5 \mathrm{~m}^{2} / \mathrm{g}\right)$. This behavior was attributed to copper presence as well as to the fine particle and well agglomerated characteristics of the powder. BET data are in accordance to observed SEM images, where the carbide powder with higher dopant content presented a less porous characteristic than the carbide with lower dopant content.

Figures 4 and 5 present adsorption-desorption isotherms of the $5 \% \mathrm{Cu}$ doped and $10 \% \mathrm{Cu}$ doped carbides, respectively. H3 hysteresis phenomena can be observed in both cases, this is characteristic of mesoporous materials, which are mainly formed by agglomerates of fine particles of platelet shape. This agglomeration gives rise to a porous material that present pores with various sizes in the shape of slices, which was observed on SEM images. 
Table 4. Surface area and pore volume data on the produced doped carbides.

\begin{tabular}{lcc}
\hline Sample & Surface area $\left(\mathrm{m}^{2} / \mathrm{g}\right)$ & Pore size $\left(\mathrm{cm}^{3} / \mathrm{g}\right)$ \\
\hline $5 \% \mathrm{Cu}-\mathrm{NbC}$ & 43.5027 & 0.096 \\
$10 \% \mathrm{Cu} \_\mathrm{NbC}$ & 37.7711 & 0.092 \\
\hline
\end{tabular}

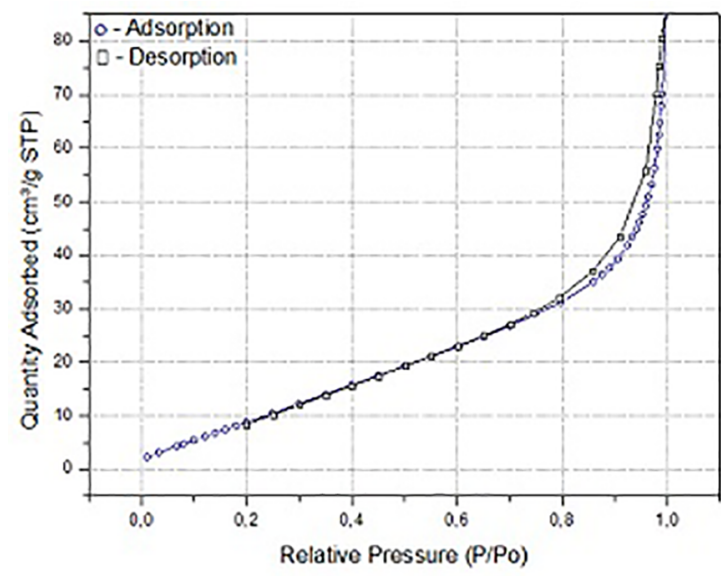

Figure 4. Adsorption isotherm for the carburization product with $5 \%$ copper.

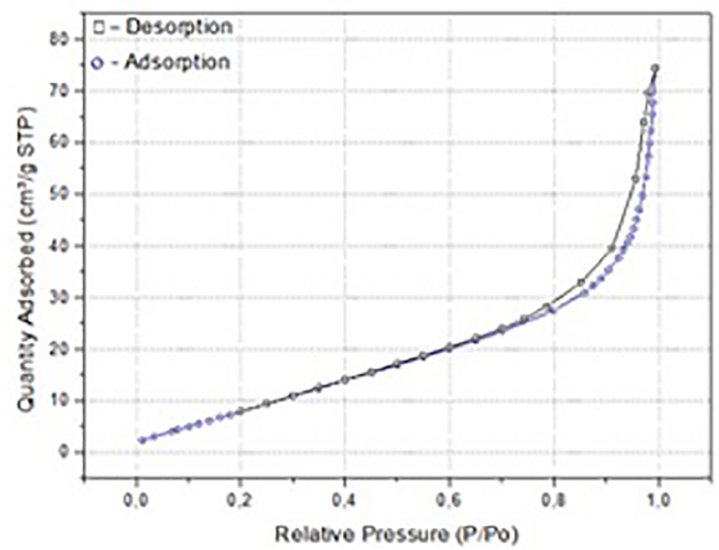

Figure 5. Adsorption isotherm for the carburization product with $10 \%$ copper.

\subsubsection{Particle size evaluation}

Figures 6 and 7 present particle size's curves for the $5 \%$ and $10 \%$ copper doped niobium carbide composites, respectively. From this analysis one can observe the particle size distribution, which is in agreement with SEM evaluation. Both curves present bimodal behavior.

The composite with the higher copper addition (Figure 7) produced agglomerates of larger size. This effect could be due to fact that at this compositional level copper can be found in a single phase (XRD analysis on section 3.1.1); therefore it could, by an electrostatic mechanism, attract other particles and form larger agglomerates.

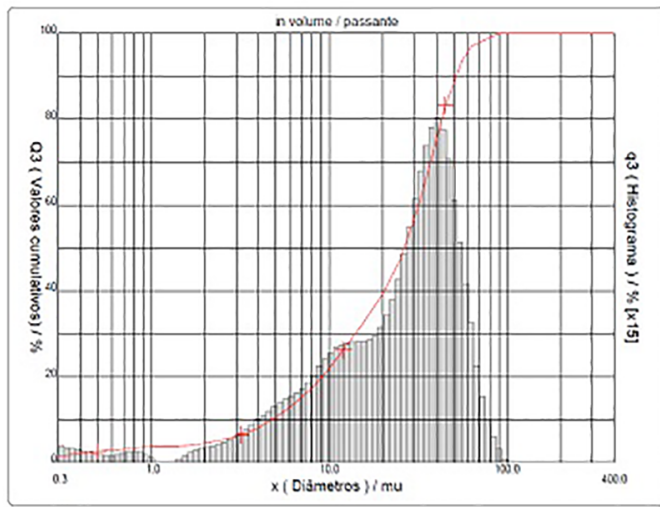

Figure 6. Particle size distribution for niobium carbide with $5 \%$ copper addition.

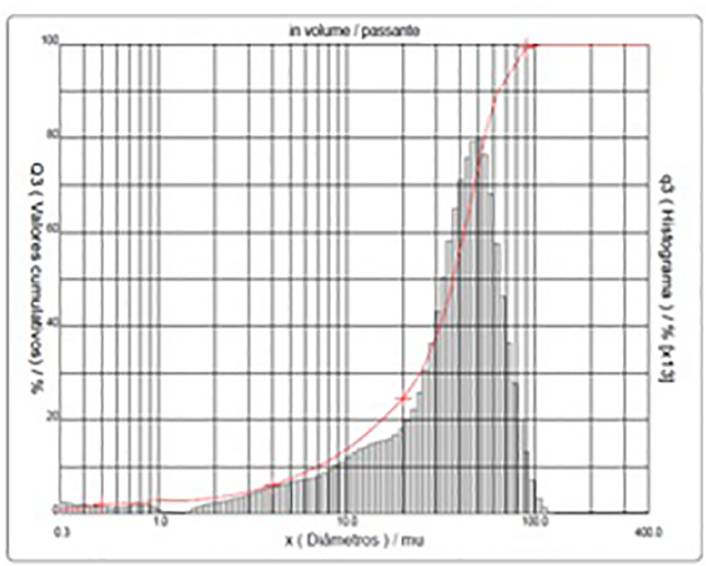

Figure 7. Particle size distribution for niobium carbide with $10 \%$ copper addition.

\section{Conclusions}

The methodology proposed in this paper to obtain niobium carbide with copper addition was considered effective as it was possible to obtain the carbide product without any trace of oxide phases on the time and temperature established.

XRD analysis confirmed the complete conversion of the starting material to carbides at $980^{\circ} \mathrm{C}$ with a $2 \mathrm{~h}$ soaking time, as well as indicated a slight diffraction angle's shift due to the dopant presence in the material. This technique also verified the presence of copper relative peaks, though only on the highest compositional level studied. The presence of the dopant metal, however, was confirmed by XRF with no significant changes from intended contents, indicating the effective presence of the dopant on the final product.

Crystal sizes evaluation by HWL method showed the increase in sizes due to the increased copper content, which, on the other hand, lead to a decrease in superficial area of the composite. This was verified through BET analysis of the powders. 
Through SEM evaluation of the materials it was possible to observe that only slight morphological changes can be observed upon increasing dopant content, those being relative, mostly, to the decrease in surface area. Images also indicated a tendency towards forming a platelet shaped material, as well as decreasing apparent porosity of the produced carbide with increasing dopant content. Particle size analysis verified a bimodal distribution of agglomerate sizes', this phenomenon was attributed to possible microstructural changes due to dopant presence.

\section{Acknowledgments}

This research group acknowledges the financial support and technical assistance provided by:

Programa de Pós-Graduação em Ciências e Engenharia de Materiais- PPGCEM;

Universidade Federal do Rio Grande do Norte- UFRN;

Laboratório de Materiais Cerâmicos e Metais Especiais - LMCME;

Laboratório de Materiais Nanoestruturados e Reatores Catalíticos - LAMNRC;

Coordenação de Aperfeiçoamento de Pessoal de Nível Superior-CAPES

Centro de Tecnologia Estratégica do Nordeste- CETENE.

\section{References}

1. Xiang H, Xu Y, Zhang L, Cheng L. Synthesis and microstructure of tantalum carbide and carbon composite by liquid precursor route. Scripta Materialia. 2006;55(4):339-342. DOI: 10.1016/j. scriptamat.2006.04.036

2. Lima MJS. Synthesis and characterization of TaC and Mixed Oxide Nanostructured Tantalum and Copper From The Precursor Oxalic Tantalum Through Reactions Gas-Solid and Solid-Solid Low Temperature. [Dissertation]. Natal: Departamento de Engenharia de Materiais, Universidade Federal do Rio Grande do Norte; 2013.

3. Fontes FAO. Protótipo de reator de cilindro rotativo para obtenção de NbC: cinética e desempenho da redução e carbonetação. [Thesis]. Natal: Centro de Tecnologia, Departamento de Engenharia Química. Universidade Federal do Rio Grande do Norte; 2003.

4. Chan JY, Kauzlarich SM. Rare-Earth Halides as Fluxes for the Synthesis of Tantalum and Niobium Carbide. Chemistry of Materials. 1997;9(2):531-534.

5. Pierson HO. Handbook of Refractory Carbides and Nitrides: Properties, Characteristics, Processing and Applications. New Jersey: Noyes Publications; 1996.

6. Gomes KKP. Sintese e caracterização do carbeto de molibdênio nanoestruturado para fins catalíticos na reação de oxidação parcial do metano. [Dissertação]. Natal: Universidade Federal do Rio Grande do Norte; 2006.
7. Ma J, Wu M, Du Y, Chen S, Jin W, Fu L, et al. Formation of nanocrystalline niobium carbide $(\mathrm{NbC})$ with a convenient route at low temperature. Journal of Alloys and Compounds. 2008;475(1-2):415-417.

8. Medeiros FFP. Sintese de carbetos de tungstênio e nióbio a baixa temperatura, através de reação gás-sólido em reator de leito fixo. [Thesis]. Natal: Centro de Tecnologia, Departamento de Engenharia Química, Universidade Federal do Rio Grande do Norte; 2002.

9. Grunsky D, Kupich M, Hofferberth B, Schroeder B. Investigation of the tantalum catalyst during the hot wire chemical vapor deposition of thin silicon films. Thin Solid Films. 2006;501(12):322-325.

10. Furimsky E. Metal carbides and nitrides as potencial catalysts for hydroprocessing. Applied Catalysis A: General. 2003;240(12):1-28.

11. Schneider SJ. Engineered Materials Handbook: Ceramics and Glasses. Volume 4. Materials Park: ASM International; 1991.

12. Toniolo JC. Síntese de pós de alumina nanocristalina por combustão em solução. [Dissertation]. Porto Alegre: Escola de Engenharia, Universidade Federal do Rio Grande do Sul; 2004.

13. Tanabe K, Okazaki S. Various reactions catalyzed by niobium compounds and materials. Applied Catalysis A: General. 1995;133(2):191-218

14. Chen Y, Zhang H, Zhang J, Ma J, Wang L, Ye H, et al. Facile synthesis, characterization and photocatalytic activity of niobium carbide. Advanced Powder Technology. 2013;24(1):207-211.

15. Souza MOG, Quadro EB, Rangel MC. Propriedades texturais e catalíticas de óxidos de ferro contendo cromo e cobre. Química Nova. 1998;21(4):428-433.

16. Jenkins SV, Chen S, Chen J. Gold-copper alloyed nanorods for metal-catalyzed organic reactions: implication of surface ligands on nanoparticle-based heterogeneous catalysis. Thetrahedron Letters. 2015;56(23):3368-3372.

17. Long BD, Umemoto $\mathrm{M}$, Todaka $\mathrm{Y}$, Othman R, Zuhailawati $\mathrm{H}$. Fabrication of high strength $\mathrm{Cu}-\mathrm{NbC}$ composite conductor by high pressure torsion. Materials Science and Engineering: $A$. 2011;528(3):1750-1756. DOI: 10.1016/j.msea.2010.11.005

18. Marques MT, Livramento V, Correia JB, Almeida A, Vilar R. Production of copper-niobium carbide nanocomposite powders via mechanical alloying. Materials Science and Engineering: A. 2005;399(1-2):382-386.

19. Hussain Z, Othman R, Long BD, Umemoto M. Synthesis of copper-niobium carbide composite powder by in situ processing. Journal of Alloys and Compounds. 2008;464(1-2):185-189.

20. Borovinskaya I, Ignatieva T, Vershinnikov V. Self-Propagating High-Temperature Synthesis of Ultrafine Tungsten Carbide Powders. In: Liu K, ed. Tungsten Carbide - Processing and Applications. Rijeka: Intech; 2012.

21. Souto MVM, Lima MJS, Barbosa CM, Gomes UU, Souza $\mathrm{CP}$, Araujo CPB. Synthesis and Characterization of $\mathrm{CuNb}_{2} \mathrm{O}_{6}$ from an Oxalic Precursor Via Solid State Reaction. Materials Research. 2016;19(4):865-869. 
22. Medeiros FFP, Silva AGP, de Souza CP. Synthesis of niobium carbide at low temperature and its use in hardmetal. Powder Technology. 2002;126(2):155-160.

23. Oliveira SA. Evaluation of the kinetic and potential $\mathrm{Nb2O5}$ obtained from a niobium complex to the formation of methyl oleate by esterification of oleic acid. [Dissertation]. Natal: Universidade Federal do Rio Grande do Norte; 2014.

24. Medeiros FFP, de Oliveira SA, de Souza CP, da Silva AGP, Gomes UU, de Sousa JF. Synthesis of tungsten carbide through gas-solid reaction at low temperatures. Materials Science and Engineering: A. 2001;315(1-2):58-62.

25. Araújo CPB, de Souza CP, Maia LMD, Souto MVM, Barbosa CM. On the synthesis of molybdenum carbide with cobalt addition via gas-solid reactions in a $\mathrm{CH}_{4} / \mathrm{H}_{2}$ atmosphere. Brazilian Journal of Chemical Engineering. 2016;33(3):577-588.

26. Souto MVM. Synthesis and characterization of CuNb2O6 and $\mathrm{CuNbC}$ through reaction solid-solid and gas-solid low temperature. [Dissertation]. Natal: Universidade Federal do Rio Grande do Norte; 2013.

27. Fontes FAO, Gomes KKP, Oliveira SA, Souza CP, Sousa JF. Niobium carbide synthesis by solid-gas reaction using a rotating cylinder reactor. Brazilian Journal of Chemical Engineering. 2004;21(3):393-403.

28. Edelstein AS, Cammarata RC, eds. Nanomaterials: Synthesis, Properties and Aplications. New York: Taylor \& Francis; 1996. 